\title{
Formulasi dan Evaluasi Sifat Fisik Lotion Ekstrak Etanol Daun Kemuning (Murraya paniculata (L) Jack) dan Daun Lidah Buaya (Aloe vera Linn)
}

\author{
Windah Anugrah Subaidah ${ }^{*}$, Wahida Hajrin ${ }^{1}$, Yohanes Juliantoni ${ }^{1}$
}

${ }^{1}$ Program Studi Farmasi, Fakultas Kedokteran, Universitas Mataram, Mataram, Indonesia.

\section{Article Info}

Received : 12 Maret 2020

Revised : 14 April 2020

Accepted: 16 April 2020

\begin{abstract}
The ultraviolet radiation and skin water loss could damage the skin. Kemuning leaves (Murraya paniculata (L) Jack) as a source of anti-oxidants and Aloe vera leaves (Aloe vera Linn) can prevent this action. This study aims to formulate and evaluate lotion containing the Kemuning leaves and Aloe vera extract. The extract of Kemuning leaves was obtained by sonication using $70 \%$ ethanol solvent. Aloe vera juice was obtained by smoothing the aloe vera gel then filtered using clean gauze. The kemuning leaves extract and aloe vera extract had formulated into lotion preparation. The physical properties of the lotion (homogeneity, type of emulsion, $\mathrm{pH}$, spreadability, and adhesion) were determined. The organoleptic test showed that the color of the lotion was pale yellow with a smooth texture and had extract scent. The lotion was showed good homogeneity, spreadability 7.31 $\mathrm{cm}, \mathrm{pH} 7$, type oil in water and adhesion 45 seconds. The physical properties parameters of lotion preparations showed that the lotion preparations had fulfilled the requirements of good preparations.
\end{abstract}

Keywords: Kemuning leaves, Aloe vera leaves, Lotion

Citation:

Subaidah, W.A., Hajrin, W., Juliantoni, H. (2020). Formulasi dan Evaluasi Sifat Fisik Lotion Ekstrak Etanol Daun Kemuning (Murraya paiculata (L) Jack) dan Daun Lidah Buaya (Aloe vera Linn). Sasambo Journal of Pharmacy, 1(1), 12-16.

\section{Pendahuluan}

Kulit memegang peranan penting untuk melindungi tubuh kita. Secara fisik kulit melindungi tubuh dari serangan eksternal seperti infeksi, bahan kimia dan alergen (Kanwar, 2018). Seiring berjalannya waktu kulit manusia dapat mengalami kerusakan. Kerusakan kulit dapat disebabkan oleh beberapa faktor eksternal seperti radiasi ion, stress psikologi, konsumsi alkohol, nutrisi yang kurang, polusi lingkungan dan paparan radiasi sinar UV. Kontribusi terbesar atau sekitar $80 \%$ kerusakan kulit disebabkan oleh radiasi sinar UV (Polj`sak \& Dahmane, 2012).

Kulit yang terpapar sinar matahari akan mengabsorbsi radiasi UV dan menghasilkan reactive oxygen species (ROS). ROS akan menimbulkan kerusakan tingkat sel seperti pada dinding sel, membrane lipid, DNA dan mitokondria . Kulit yang terpapar lama oleh sinar matahari akan timbul eritema dan penurunan produksi kolagen sehingga menimbulkan manifestasi klinis berupa penuan dini hingga dapat meyebabkan kanker kulit (Helfrich et al., 2008).

ROS yang disebabkan oleh sinar matahari dapat dicegah dengan penggunaan zat antioksidan (Stojiljkovi et al., 2014). Antioksidan dapat berasal dari alam maupun sintetik. Antioksidan yang berasal dari alam lebih disenangi karena efek samping yang kurang dibanding sintetik. Salah satu tanaman yang memiliki khasiat antioksidan adalah daun kemuning (Murraya paniculata (L) Jack). Dilaporkan IC50, Gallic Acid Equivalent (GEA) dan Quarcetin Equivalent ekstrak etanol daun kemuning berturut-turut sebesar

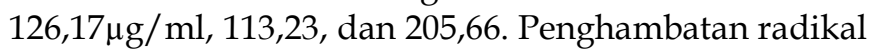
bebas ekstrak daun kemuning diduga bersumber dari 4'- hidroksi-3,5,6,7,3', ,5'- heksametoksi flavon. Senyawa ini mengandung $\mathrm{OH}$ fenolik yang dapat bertidak sebagai penangkap radikal bebas (Azlia et al., 2019). 
Penyebab kerusakan kulit yang lainnya yakni hidrasi atau proses penguapan air pada stratum korneum dan kelenjar keringat. Kandungan air sebesar $10-20 \%$ pada stratum korneum dibutuhkan untuk membuat kulit lembut dan lentur. Kulit yang kering karena kehilangan kelembapan dapat menyebabkan kulit kasar, pecah-pecah, gatal dan eritema yang disebabkan oleh dilatasi pembuluh darah kapiler pada dermis (Azlia et al., 2019). Bahan alam yang dapat digunakan untuk melindungi kehilangan air pada stratum korneum adalah Lidah buaya (Aloe vera Linn.). Lidah buaya mengandung vitamin A, B, C, E, kalsium, asam amino, enzim dan polisakarida. Kandungan ini yang berkhasiat sebagai moisturizing agent (Bhuvana et al., 2014), dimana ekstrak lidah buaya 3\% dapat menurunkan kadar transepidermal water loss (Sharma et al., 2014).

Untuk memudahkan aplikasi sari lidah buaya diformulasikan ke dalam bentuk sediaan krim yang menunjukkan terdapat kenaikan kelembapan pada kulit (Aryani et al., 2019). Sedangkan formulasi ekstrak daun kemuning dalam sediaan farmasi masih sangat jarang. Oleh sebab itu, maka diformulasikanlah kedua ekstrak ke dalam sediaan farmasi yakni lotion. Sediaan lotion merupakan sediaan topikal yang digunakan sebagai pelindung kulit yang aplikasinya pada bagian kulit tangan dan tubuh. Pemilihan bentuk sediaan lotion disebabkan sediaan lotion mudah menyebar dan merata ketika diaplikasikan sehingga memberikan kenyamanan pada pengguna (Lieberman, 1998). Berdasarkan uraian tersebut maka penelitian ini bertujuan untuk memformulasikan sedian lotion dari ekstrak etanol daun kemuning (Murraya paniculata (L) Jack dan lidah buaya (Aloe vera Linn) yang kemudian dievaluasi sifat fisik lotion tersebut.

\section{Metode}

\section{Alat dan Bahan}

Alat yang digunakan dalam penelitian ini yakni : timbangan analitik, sonikator, kertas saring, penangas air, kertas $\mathrm{pH}$, kaca beserta beban 50g: 100r: $200 \mathrm{~g}$, kaca obyek beserta beban $1 \mathrm{~kg}$, alat uji daya lekat, alat-alat gelas dan blender

Bahan yang digunakan dalam penelitian ini yakni : daun kemuning (Murraya paniculata (L) Jack, lidah buaya (Aloe vera Linn), etanol $70 \%$, asam stearat, trietanolamin, setil alkohol, parafin cair, gliserin, metil paraben, propil paraben, aqua rosae, aquadest dan metilen biru.

\section{Pengumpulan dan Pengolahan Sampel}

Sampel lidah buaya dan daun kemuning diperoleh dari Petulan Indah Kabupaten Lombok barat. Sampel yang dikumpulkan kemudian dicuci dengan air mengalir. Daun kemuning yang telah bersih kemudian dikeringkan di bawah sinar matahari dengan menggunakan kain hitam sebagai tutup. Daun kemuning yang telah kering kemudian dihaluskan hingga menjadi serbuk.

\section{Pembuatan Ekstrak Daun Kemuning}

Ekstrak daun kemuning diperolah dengan cara sonikasi. Serbuk simplisia diekstraksi dengan pelarut etanol $70 \%$ kemudian dimasukkan ke dalam alat sonikasi. Kemudian dipisahkan antara maserat dan filtratnya. Maserat direekstraksi sebanyak dua kali. Ekstrak cair yang diperoleh kemudian dipekatkan di atas penangas air pada suhu $55^{\circ} \mathrm{C}$ hingga diperoleh ekstrak kental.

\section{Pembuatan Sari Lidah Buaya}

Daging lidah buaya dipisahkan dari kulit luar. Kemudian sebanyak 50 gr daging lidah buaya segar dihaluskan menggunakan blender. Sari yang diperoleh kemudian disaring menggunakan kain kasa bersih.

\section{Pembuatan Sediaan Lotion}

Lotion ekstrak daun kemuning dan sari lidah buaya dibuat dengan cara melebur secara terpisah fase minyak (asam stearat, setil alkohol, parafin cair dan propil paraben) dan fase air (gliserin, metil paraben, TEA dan aqua destilata). Fase minyak ditambahkan ke dalam fase air sambil terus diaduk. Ekstrak daun kemuning dan sari lidah buaya ditambahkan ke dalam basis lotion kemudian diaduk hingga homogen. Terakhir ditambahkan aqua rosae aduk hingga homogen. Rancangan formula dapat dilihat pada tabel 1.

Tabel 1: Rancangan formula lotion ekstrak etanol daun kemuning dan lidah buaya

\begin{tabular}{ll}
\hline Nama Bahan & Konsentrasi (\%) \\
\hline Ekstrak daun kemuning & 2 \\
Sari lidah buaya & 3 \\
Asam stearate & 2,5 \\
Trietanolamin & 2 \\
Setil alkohol & 5 \\
Parafin cair & 8 \\
Gliserin & 5 \\
Metil paraben & 0,1 \\
Propil paraben & 0,1 \\
Aqua rosae & q.S \\
Aqua destilata & Ad 100 \\
\hline
\end{tabular}

\section{Evaluasi Sediaan}

Uji organoleptis

Pengujian terhadap lotion daun kemuning dan lidah buaya dilakukan dengan mengamati warna, tekstur dan aroma sediaan. 


\section{Uji homogenitas}

Pengujian homogenitas sediaan dengan cara diambil sebanyak 1 gram krim pada bagian atas, tengah, dan bawah. Sampel dioleskan pada object glass kemudian diamati sebaran sediaan ada tidaknya partikel-partikel kasar atau gumpalan.

\section{Uji Tipe emulsi}

Pengujian tipe emulsi dilakukan dengan dua metode yakni metode pengenceran dengan air dan metode pewarnaan. Metode pengenceran dengan cara sebanyak 0,5 gram sediaan diambil kemudian diencerkan dengan air sebanyak $50 \mathrm{ml}$ air. Jika sediaan dapat diencerkan maka tipe emulsi adalah tipe M/A. Metode pewarnaan dengan cara sediaan mengambil 1 gram sediaan kemudian dimasukkan kedalam vial. Sediaan ditetesi dengan larutan metilen biru. Tipe emulsi M/A jika warna biru terdispersi ke seluruh emulsi.

\section{Uji pH}

Pengujian $\mathrm{pH}$ sediaan dengan cara mencelupkan $\mathrm{pH}$ stick kedalam sediaan. Hasilnya dibandingkan dengan standar $\mathrm{pH}$ yang sudah diketahui nilai pHnya. Nilai $\mathrm{pH}$ yang baik sesuai dengan $\mathrm{pH}$ fisiologis kulit yakni 4,5-6,5.

\section{Uji Daya sebar}

Sebanyak 0,5 gram sediaan diletakkan di atas kaca kemudian dibiarkan selama 1 menit. Luas daerah yang terbentuk diukur luasnya. Beban seberat 50, 100, 150 dan 200 gram didiamkan selama 1 menit dan diukur daya sebarnya. Daya sebar yang baik memiliki ukuran sebesar 5-7 cm (Garg et al., 2002).

\section{Uji Daya lekat}

Pengujian daya lekat dilakukan dengan cara menimbang sebanyak 0,5 gram sampel kemudian dioleskan di atas obyek gelas. Diletakkan obyek gelas yang lain pada sediaan tersebut kemudian ditekan dengan beban $1 \mathrm{~kg}$ selama 5 menit. Obyek gelas kemudian dipasang pada alat uji yang diberi beban seberat 80 gram kemudian dicatat waktu yang dibutuhkan untuk kedua obyek gelas memisah. Persyaratan daya lekat yang baik untuk sediaan topikal adalah lebih dari 4 detik.

\section{Analisis Data}

Data yang diperoleh yakni hasil pengamatan organoleptis, hasil uji homogenitas, tipe emulsi, $\mathrm{pH}$, daya sebar dan daya lekat. Data hasil uji kemudian dibandingkan dengan syarat fisik sediaan krim yang baik.

\section{Hasil dan Pembahasan}

Pengumpulan sampel daun kemuning dan lidah buaya dilakukan di Petulan Indah Kabupaten Lombok barat di waktu pagi hari. Daun Kemuning yang diambil adalah yang berwarna hijau, daun yang diambil mulai dari bagian bawah pucuk hingga ke bagian pangkal ranting. Daun kemuning dan lidah buaya yang telah dikumpulkan kemudian dibersihkan dengan cara dicuci di bawah air yang mengalir. Pembuatan serbuk simplisia daun kemuning dengan cara dikeringkan di bawah sinar matahari selama 3 hari. Tujuan pengeringan adalah untuk menghilangkan kandungan air pada daun, agar simplisia tidak mudah ditumbuhi jamur atau bakteri. Daun kemuning yang telah kering kemudian disortasi kering dan diblender untuk memperkecil ukuran daun.

Simplisia kemudian diekstraksi dengan cara sonikasi. Ekstraksi dengan cara sonikasi digunakan untuk memperoleh kandungan antioksidan yang tinggi dalam waktu yang singkat. Prinsip ektraksi sonikasi yakni gelombang ultrasonik akan memecah dinding sel tanaman sehingga kandungan yang berada dalam sel akan mudah keluar (Sholihah et al., 2017). Ekstrak kental yang diperoleh sebanyak 30,15 gram dengan persentase rendamen sebesar $12,06 \%$. Hasil ektraksi ini lebih sedikit jika dibandingkan dengan hasil ekstraksi yang di lakukan Wardani (2019) sebesar 27,60 \%. Perbedaan hasil ektraksi yang diperoleh dapat disebabkan oleh perbedaan tempat tumbuh.

Secara organoleptis ekstrak daun kemuning berwarna cokelat kehijauan dan berbau khas sperti yang tertera pada tabel 2. Organoleptis sari lidah buaya yang diperoleh yakni warna putih bening, tidak berbau dan tekstur cair. Hasil uji organoleptis sari lidah buaya tertera pada tabel 2.

Proses pembuatan lotion dengan tipe M/A dilakukan dengan cara melebur masing-masing fase minyak dan air pada tempat yang terpisah dengan suhu berkisar $70-80^{\circ} \mathrm{C}$. Fase minyak kemudian dimasukkan kedalam fase air dan diaduk hingga terbentuk basis lotion. Setelah suhu turun kemudian ditambahkan ekstrak daun kemuning dan sari lidah buaya. Ekstrak ditambahkan pada tahap akhir agar ekstrak terjerap dalam basis krim yang sudah homogen.

Tabel 2. Pengamatan organoleptis ekstrak daun kemuning, sari lidah buaya dan lotion ekstrak daun kemuning dengan lidah buaya.

\begin{tabular}{llll}
\hline Parameter & $\begin{array}{l}\text { Ekstrak daun } \\
\text { kemuning }\end{array}$ & $\begin{array}{l}\text { Sari lidah } \\
\text { buaya }\end{array}$ & Lotion \\
\hline Warna & $\begin{array}{l}\text { Cokelat } \\
\text { kehijauan }\end{array}$ & Putih bening & Kuning \\
Bau & Khas ekstrak & $\begin{array}{l}\text { Tidak } \\
\text { berbau }\end{array}$ & $\begin{array}{l}\text { Khas } \\
\text { ekstrak }\end{array}$ \\
\hline
\end{tabular}




\begin{tabular}{|c|c|c|c|}
\hline Tekstur & Kental & Cair & $\begin{array}{l}\text { kemuning } \\
\text { Halus dan } \\
\text { lembut }\end{array}$ \\
\hline
\end{tabular}

Hasil uji organoleptis menunjukkan sediaan lotion berwarna kuning, aroma khas ekstrak kemuning dan memiliki tekstur krim yang halus dan lembut. Aroma dan warna yang dihasilkan lotion ini tergantung dari konsentrasi ekstrak kemuning yang digunakan, karena sari lidah buaya tidak berwarna serta aromanya tidak menyengat. Hasil uji organoleptis lotion ekstrak daun kemuning dan sari lidah buaya terlihat pada tabel 2 .

Hasil pengujian homogenitas pada sediaan lotion ekstrak daun kemuning dan sari lidah buaya menunjukkan bahwa formula Lotion yang dibuat memiliki karakteristik yang homogen. Dikatakan homogen apabila pada saat pengujian tidak ada partikel-partikel kasar atau gumpalan. Lotion tercampur secara merata serta warna yang homogen (Buah et al., 2017).

Tabel 3. Hasil uji homogenitas, tipe emulsi dan $\mathrm{pH}$

\begin{tabular}{ll}
\hline Parameter & Hasil \\
\hline Homogenitas & Homogen \\
Tipe emulsi : & \\
Metode pengenceran & $\mathrm{M} / \mathrm{A}$ \\
Metode pewarnaan & $\mathrm{M} / \mathrm{A}$ \\
$\mathrm{pH}$ & 7 \\
\hline
\end{tabular}

Pengujian tipe emulsi dilakukan untuk mengetahui tipe emulsi sediaan. Tipe emulsi sediaan yang diharapkan yakni tipe M/A. Emulsi tipe M/A terjadi disebabkan pencampuran TEA dengan asam stearat. Campuran ini akan membentuk sabun anionik dan menghasilkan emulsi tipe M/A yang stabil dan halus (Jones, 2008). Pada pengujian tipe emulsi sediaan lotion tipe emulsi yang diperoleh adalah tipe M/A hal ini sesuai dengan hasil uji yang diperoleh. Pada uji pengenceran dengan air, emulsi dapat diencerkan air karena fase terluar emulsi tersebut adalah air. Pada pengujian tipe emulsi dengan pewarnaan menggunakan metilen biru emulsi dapat terwarnai karena metilen biru larut dalam air dan fase terluar dari emulsi adalah air (Aulton, 2001).

Pengujian $\mathrm{pH}$ sediaan dilakukan dengan tujuan untuk mengetahui tingkat keamanan sediaan. Jika $\mathrm{pH}$ sediaan rendah atau asam maka akan menyebabkan iritasi pada kulit, jika $\mathrm{pH}$ sediaan tinggi atau basa makan akan menyebabkan kulit kering ketika diaplikasikan (Barel et al., 2001). pH sediaan yang baik berkisar antara 4-7 (Lambers et al., 2017). Berdasarkan tabel 3 hasil uji $\mathrm{pH}$ yakni 7 hal ini telah sesuai dengan rentang $\mathrm{pH}$ yang disarankan untuk sediaan topikal. $\mathrm{pH}$ sediaan sangat dipengaruhi oleh bahan tambahan yang digunakan. TEA merupakan basa lemah sehingga dengan adanya penambahan TEA akan menghasilkan $\mathrm{pH}$ sediaan yang mendekati $\mathrm{pH}$ basa, terlihat dari $\mathrm{pH}$ sediaan yang mencapai $\mathrm{pH} 7$.

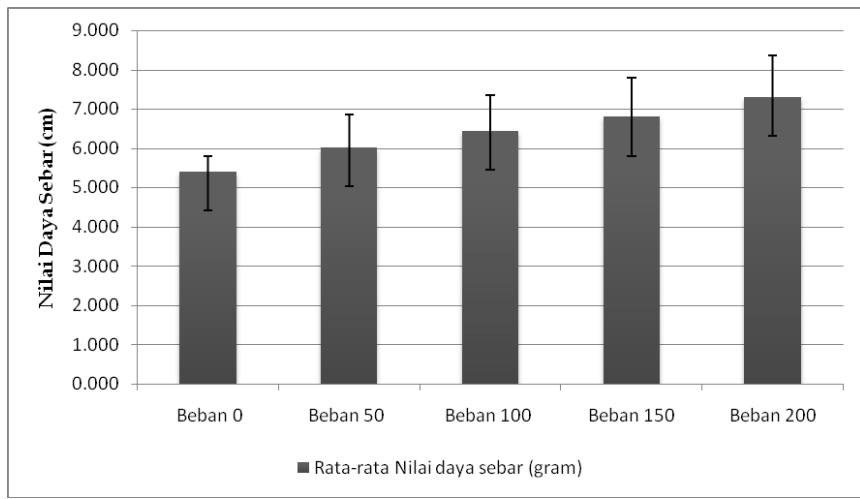

Gambar 1. Histogram peningkatan nilai daya sebar dengan meningkatnya beban yang diberikan pada formulasi lotion ekstrak daun kemuning dan daun lidah buaya

Hasil uji daya sebar lotion ekstrak daun kemuning dan daun lidah buaya seperti pada gambar 1. Rata-rata penyebaran lotion sebelum diberikan beban sebesar $5,4 \mathrm{~cm}$, daya beban 50 gram sebesar 6,03 $\mathrm{cm}$, daya beban 100 gram sebesar $6,45 \mathrm{~cm}$, daya beban 150 gram sebesar $6,81 \mathrm{~cm}$ dan daya beban 200 gram sebesar 7,31 cm. Hasil uji daya sebar menunjukkan bahwa lotion telah memenuhi persyaratan daya sebar lotion yang baik yakni 5-6 cm (Garg et al., 2002). Pengamatan daya sebar dilakukan untuk mengetahui kemampuan sediaan menyebar di atas permukaan kulit. Penyebaran sediaan lotion yang baik akan memudahkan aplikasi sediaan lotion di atas permukaan kulit. Sebaran lotion yang merata akan memberikan efek lebih optimal. Daya sebar krim yang luas juga akan memberikan kontak antara sediaan dengan kulit semakin luas sehingga zat aktif yang terkandung dalam lotion akan menyebar luas dan merata (Duggin, 1996).

Hasil uji daya lekat sediaan lotion ekstrak daun kemuning dan daun lidah buaya sebesar $45 \pm 2,64$ detik. Hasil uji daya lekat lotion telah sesuai dengan persyaratan sediaan topikal yakni $<4$ detik. Daya lekat yang baik menunjukkan lama kontak antara permukaan kulit dengan sediaan. Semakin besar daya lekat menunjukkan semakin lama kontak antara sediaan dengan kulit sehingga absorbsi zat aktif lebih optimal (Pujiastuti \& Kristiani, 2019).

\section{Kesimpulan}

Berdasarkan hasil evaluasi terhadap sifat fisik yang dilakukan pada lotion ekstrak daun kemuning dan lidah buaya dapat disimpulkan bahwa sediaan 
lotion telah memenuhi persyaratan sediaan lotion yang baik. Pengamatan organoleptis menunjukkan lotion berwarna kuning beraroma khas ekstrak daun kemuning dengan tekstur halus. Pengujian homogenitas tidak terdapat partikel kasar, pengujian daya sebar 7,31 cm, $\mathrm{pH} \mathrm{7,} \mathrm{tipe} \mathrm{lotion} \mathrm{minyak} \mathrm{dalam} \mathrm{air}$ dan daya lekat 45 detik.

\section{Daftar Pustaka}

Aryani, R., Anggriani, A., Hartiwan, M., \& Nurlela, S. (2019). Uji Efektivitas Krim Pelembab Yang Mengandung Gel Daun Lidah Buaya ( Aloe Vera Linn .) Dan Etil Vitamin C. Jurnal Ilmiah Farmasi Farmasyifa, 2(1), 52-61.

Aulton, M. E. (2001). Pharmaceutics: The science of dosage form design. Pharmaceutics: The science of dosage form design. https://doi.org/10.1016/01683659(89)90050-3

Azlia, K., Syazili, A., Syahrul, M., \& Nasution, H. (2019). Review Efek Antioksidan pada Kemuning ( Murraya paniculata ( L .) Jack ) Review of Antioxidant Activity of Kemuning ( Murraya paniculata ( L .) Jack ). Majority, 8, 265-272.

Barel, A. O., Paye, M., \& Maibach, H. I. (2001). Handbook Of Cosmetic Science and Technology. New York: Marcel Dekker.

Bhuvana, K. B., Hema, N. G., \& Patil, R. T. (2014). Review on aloe vera. International Journal of Advanced Research, 2(3), 677-691.

Buah, E., Solanum, T., \& Candida, T. (2017). Jurnal Riset Sains dan Teknologi, 1(1), 15-21.

Duggin, G. (1996). Softening Skin with Emollient Ingredients. In Manufacturing Chemist (pp. 27-31).

Garg, A., Aggarwal, D., Garg, S., \& Singla, A. K. (2002). Spreading of Semisolid Formulations. Pharmaceutical Technology, (September).

Helfrich, Y., Sachs, D., \& Voorhees, J. (2008). Overview of skin aging and photoaging. Dermatol Nurs, 20(3).

Jones, D. (2008). Pharmaceutics - Dosage Form and Design. London: Pharmaceutical Press.

Kanwar, A. . (2018). Skin barrier function. The Indian Journal of Medical Research, 147(1).

Lambers, H., Piessens, S., Bloem, A., Pronk, H., \&
Finkel, P. (2017). Natural skin surface pH Is on average below 5 , which is beneficial for its resident flora Natural skin surface $\mathrm{pH}$ is on average below 5 , which is beneficial for its resident flora. International Journal of Cosmetic Science, (November 2006). https://doi.org/10.1111/j.14672494.2006.00344.x

Lieberman, A. H. (1998). Pharmaceutical Dosage Form, Disperse System. Philadelphia: Marcel Dekker.

Polj`sak, B., \& Dahmane, R. (2012). Free Radicals and Extrinsic Skin Aging. Dermatology Research and Practice, 2012. https://doi.org/10.1155/2012/135206

Pujiastuti, A., \& Kristiani, M. (2019). Formulasi dan Uji Stabilitas Mekanik Hand and Body Lotion Sari Buah Tomat ( Licopersicon esculentum Mill .) sebagai Antioksidan Formulation and Mechanical Stability Test for Hand and Body Lotionfrom Tomato Juice ( Licopersiconesculentum Mill .) as Antioxi. Jurnal Farmasi Indonesia, 16(1), 42-55.

Sharma, P., Kharkwal, A., Kharkwal, H., \& Abdin, M. Z. (2014). A Review on Pharmacological Properties of Aloe vera. International Journal of Pharmaceutical Sciences Review and Research, (December).

Sholihah, M., Ahmad, U., \& Budiastra, I. wayan. (2017). Aplikasi Gelombang Ultrasonik untuk Meningkatkan Rendemen Ekstraksi dan Efektivitas Antioksi dan Kulit Manggis Application. Jurnal Keteknikan Pertanian, 5(2), 161168.

Stojiljkovi, D., Pavlovi, D., \& Arsi, I. (2014). Oxidative Stress, Skin Aging and Antioxidant Therapy, 31(4), 207-217. https://doi.org/10.2478/afmnai2014-0026 